\title{
Contextual Effects of Redistricting on Old and New Voters: Sometimes Newcomer Ignorance Can Mean Electoral Bliss for the Incumbent
}

\author{
Richard Born \\ Vassar College \\ born@vassar.edu
}

\begin{abstract}
Research directed at the effects of congressional redistricting on individual voters mainly has centered on transplanted constituents' lesser tendency relative to that of retained constituents to back the incumbent. Differences in the impacts that district-level (i.e., contextual) factors have on the two types of voters, however, have been slighted. In this study, we find that campaign spending affects transplanted and retained voters commensurately, but that the effects of district partisan homogeneity in raising the odds of a pro- incumbent vote and of member ideological extremity in decreasing these odds are only exerted on retained constituents. The explanation seems to be that information conveyed by candidate spending, which emerges only over the duration of the campaign, is equally accessible to new and old constituents alike, whereas old constituents have had longer opportunity to process information about district partisanship and incumbent ideology. From the reelection perspective of incumbents who represent districts with unfriendly partisanship or who have extreme ideology, the non-responsiveness of new constituents to these latter two contextual factors is therefore an electoral asset, implying that such members, contrary to the conventional wisdom, benefit from large-scale transfusions of new constituents at redistricting time.
\end{abstract}

\section{Introduction}

Much work in the extensive literature on U.S. House redistricting has focused upon the electoral role played by constituents newly appended to an existing member's constituency as a result of redrawn district lines. With partisanship held constant, "new" (i.e., transplanted) constituents have been found to vote less strongly for the incumbent than do "old" (i.e., retained) constituents, especially when the incumbent's party is the recipient of an unfavorable regional or national election tide (Petrocik and Desposato, 1998, 625- 29; Crespin, 2005, 259; McKee, Teigen, and Turgeon, 2006, 315; McKee, 2008a, 126-29; Hood, III and McKee, 2010, 351-54; Yoshinaka and Murphy, 2011, 437-38; Hood, III and McKee, 2013, 208; McKee, 2013, 636). The chief causal factor appears to be the difficulty faced by the member in establishing over the relatively brief period available before election day "personal vote" connections with newly appended constituents; i.e., non-party-based relationships stemming from name recognition and constituency service. Thus, unmoored by the centripetal force of incumbency, these constituents' voting behavior closely resembles that in open seat districts (Ansolabehere, Snyder, Jr., and Stewart, III, 2000, 26; Rush, 2000, 55).

Aside from less proclivity to support incumbents, however, there is only limited knowledge about differences between new and old constituents. This is particularly true with regard to the question of how district-level (i.e., contextual) characteristics associated with the 
candidates in a campaign and the composition of the district affect the behavior of the two types of voters. A full accounting of individual voting behavior, regardless of whether any connection to redistricting is being considered, demands recognition that the geographical context in which such behavior is embedded matters; i.e., contextual environment, as McDaniel puts it, is more than just a "neutral container" $(2014,5)$. Thus, contextual variables capturing various elements of the campaign, such as spending levels of incumbents and challengers and whether the challenger has elected office experience, are a staple of the general congressional election literature.

Contextual variables tapping the political and demographic composition of the constituency also have been employed in a variety of non-redistricting voting studies, albeit to a lesser extent. For example, Pattie and Johnston find that the prevailing partisanship in British polling districts helps explain party switching by individual voters in these districts from the 1987 to the 1992 general election (2000, 48-50). Likewise, Burbank's comparative study of voting in the 1987 U.K. general election and 1988 U.S. presidential election shows that political party dominance in the local community, as measured by constituent perceptions, has significant effects on individual voting behavior (1997, 120-26). In a third example, this time focusing on states as the geographical unit of interest, Gelman and Hill (2007, 310-14) and Gelman, Park, Shor, Bafuni, and Cortina (2008, 43-54) demonstrate that while higher income respondents within states are more likely to cast votes for Republican presidential candidates, states with higher average incomes have exerted a pro-Democratic pull upon their residents in recent elections.

With regard to congressional redistricting, however, the effects of context have been given short shrift, despite reasons to think that new and old voters may interact differently with various contextual factors. Based upon an analysis of California census blocks that were retained in U.S. House members' districts after redistricting or that were newly shifted to their districts, work by Desposato and Petrocik does draw the conclusion that new constituents in 1992 and 1994 were influenced more to vote against the incumbent than were old constituents by the ratio of challenger to incumbent spending (which they use as an indicator of challenger quality) (2003, 24-28; 2005, 48-57). Their study does not deal with individual-level survey data per se, however, instead relying upon interactions between census block variables to make inferences about the behavior of individual voters. Similar analysis by them of California state assembly districts fails to turn up any clear-cut pattern involving responsiveness to campaign spending. In another aggregate data study - - this time centered on turnout rather than vote choice - - Hayes and McKee find for Texas voting tabulation districts after the state's 2002, 2004, and 2006 redistrictings that there was only a mixed tendency for total campaign spending to enhance congressional election turnout more in newly appended areas than in retained areas (2009, 1014-19). Accompanying analysis of 1992 ANES survey data leads them to a similar verdict that higher campaign spending does not consistently have a greater effect on new constituent turnout $(2009,1010-14)$. 
While the contextual effects of spending generated by redistricting, despite the lack of consensus as to their operation, have at least been touched upon, there is the wholly unaddressed question of whether another campaign variable - - challenger quality - - has differential impacts. As just stated, Desposato and Petrocik rely upon the ratio of challenger to incumbent spending as a proxy for challenger quality, but the more direct measure of quality that has been used in the general congressional election literature is whether the challenger either in the past or present has held some form of elected office. A reasonable expectation is that both spending and challenger quality should have greater impact on new constituents, given these voters' relative lack of personal vote information about the incumbent himself or herself.

Likewise slighted in redistricting studies is the question of how the two kinds of voters are influenced by the population composition of the new district. Desposato and Petrocik do include a variable in their work tapping Democratic registration percentages within census blocks, but the form of their analysis does not address the question of whether blocks new to a district differ from old blocks in their electoral responsiveness to such registration percentages (2003, 22-24; 2005, 48-52). Here, the finding from the general literature on voting, as evidenced in the works cited above by Pattie and Johnston and by Burbank, is that "individuals living in areas predominantly supporting one party are influenced to vote for that party" (Books and Prysby, 1988, 216). This can occur in two basic ways: through social interaction, and through personal perceptions (Books and Prysby, 1988, 221-22; Books and Prysby, 1991, 48-50; Burbank, $1997,115-17)$. Social interaction, even in an era of social media, has a heavy spatial dimension. When people belonging to a single party are dominant in a geographical area, one's political conversations, ceteris paribus, would disproportionately be with neighbors and acquaintances holding this partisanship, and the messages conveyed about the House member, who quite likely comes from the same party, would be very complimentary. A second possibility is that even without such interaction, constituents themselves still might be able to perceive the prevailing political leanings of the community from letters to the editor, local news reports of past election outcomes, etc. A desire to conform to this dominant partisanship in voting behavior may then be the consequence for these constituents. ${ }^{1}$

Paralleling the arguments outlined above in the cases of campaign spending and challenger quality cues, voters moved into an incumbent's district likely would also be more in need of cues arising from the partisan makeup of the district in light of their scarcity of knowledge about the incumbent himself/herself. The other side of the coin, however, which we suspect outweighs the influence of this factor, is that new voters probably have greater difficulty assessing

\footnotetext{
${ }^{1}$ Books and Prysby also discuss the "information flow" explanation as a third way by which contextual effects may be transmitted. This explanation focuses on openness to new information and the odds that people will consequently alter their opinions. But as the authors acknowledge, the argument has only been presented in fragmentary mode. Furthermore, its basic tenets to some extent seem subsumable within the social interaction and perceptual frameworks, in that both focus on the form in which contextual information is transmitted to the individual (Books and Prysby, 1988, 222; Books and Prysby, 1991, 50).
} 
district partisanship in the first place. Changes in the partisan composition of most districts induced by redistricting will be relatively modest and retained constituents can be expected to experience a considerably more familiar political landscape than that experienced by those shifted from one district to another. ${ }^{2}$ Thus, longer term residents would be more likely to have neighbors and acquaintances who could pass on positive cues about the incumbent. In addition, they would have greater ability to discern district partisanship on their own through extended perceptual experience, even though some of this advantage over transplanted constituents would be mitigated in cases where the latter had been transferred from areas with media markets that covered both the old and new member. ${ }^{3}$ On the whole, the situation with regard to district partisan homogeneity should be different than that involving the variables of spending or challenger quality, where new and old constituents alike will have had exposure to such campaign stimuli for approximately the same length of time. Thus, our expectation is that the voting impact of district partisanship would be greater for retained constituents.

A final district-level contextual variable that has been overlooked in previous research on redistricting is the ideological extremity of the incumbent up for reelection. At least in a broad sense, constituents are aware of where their incumbent stands ideologically and to take this placement into account at election time. In particular, the general voting literature shows that with the partisanship of the constituency controlled, members with relatively extreme roll call records receive smaller reelection percentages. The impact of roll call extremity, in fact, has been found to be commensurate with that of variables such as campaign spending (Canes-Wrone, Brady, and Cogan, 2002, 132-37). Other studies by Ansolabehere, Snyder, Jr., and Stewart, III (2001, 151-52) and by Erikson and W right $(2013,105-08)$ likewise have confirmed that ideology matters. It would be surprising, however, were this relationship to be equally strong for transplanted and continuing constituents, given what, in all probability, is lesser familiarity of the former voters with their new member's legislative record. The same arguments as before with regard to district partisan homogeneity presumably apply; i.e., even though new voters have a greater need for cues about the member in light of their lack of a personal vote connection, fewer interactions with long-term residents of the new district and less knowledge of the member's

\footnotetext{
${ }^{2}$ Specifically, across the 1992, 2002, and 2012 elections that will be analyzed in this study, we compute mean change of 2.7 percent in district partisanship caused by redistricting, and median change of 1.5 percent. These figures result from using a district's Democratic share of the two-party presidential vote as the indicator of partisanship, and then calculating the absolute value of the difference between the actual presidential vote resulting in the most recent pre-redistricting election and the presidential vote recomputed to correspond with the new district lines. New districts that did not have a clear-cut pre-redistricting predecessor have been dropped from these calculations. (Complete data are available by request.)

${ }^{3}$ Note, however, that lower congruence between congressional district and media market reduces the ability of constituents to recall incumbents (Winburn and Wagner, 2010,78-81). Thus, constituents transplanted from areas where the media cover more than one incumbent still could be expected to have a shortfall in recall of the new member compared to that of retained constituents.
} 
legislative record absorbed through prolonged media exposure would make them less cognizant of member ideology and hence less able to vote on this basis. ${ }^{4}$

In this study, we shall analyze how all four of the contextual effects outlined above operate upon new and old constituents in districts with incumbents seeking reelection. Individual-level survey data are utilized, so that we will not be forced to make inferences about the behavior of individuals on the basis of aggregate-level findings. The elections to be covered are 1992, 2002, and 2012, the only immediate post-redistricting elections for which it is possible to extract from ANES surveys the requisite data on whether voters have switched districts. ${ }^{5}$

\section{Data and Methods}

Data for the above elections will be combined together in our analysis. ${ }^{6}$ We perform multilevel analysis with three different levels, in which individual voters are nested within congressional districts, and congressional districts are nested within election years. ${ }^{7}$ At the lowest, individual-voter level, fixed effects for both intercept and slope coefficients are computed, while at the two higher, contextual levels, random effects variances for the intercepts are calculated. The primary advantage of employing multilevel analysis, rather than simply entering at a single level the contextual variables alongside the individual-level variables, is that in the later situation, standard errors of the parameters will be biased downward because of lack of independence among a contextual grouping's cases; i.e., such cases bear similarity to one another because of the common influence exerted by the contextual variables (Steenbergen and Jones, 2002, 220; Bickel, $2007,9-12$ ). Aside from the general problem posed for significance testing by underestimation

4 The same caveat as above, however, applies here: some transplanted constituents from district with media markets covering multiple members will probably have a sense of the new incumbent's ideology for this reason.

5 The 1992 and 2002 datasets we utilize contain variables directly indicating whether a respondent's district was switched by redistricting from the previous election. No such variable existed for 2012 , so we relied here upon the district number information for the respondent provided just before and just after redistricting. This meant comparing the pre- and post-district numbers to determine whether the respondent's member stayed the same across both elections. Earlier elections lacked either kind of information. The 1982 ANES contains no direct indicator of switching; furthermore, while a respondent's district in 1982 is identified, his/her prior district in 1978 - - not 1980 - - accompanies this listing. Some respondents from 1978 to 1980 would have moved to a new district, and the new district might have remained the same after redistricting. Thus, based on the 1978 identification, they would be improperly classified as having been switched to a new district as a result of redistricting. Alternatively, it is possible that the 1978 district of a respondent who moved to a new district in 1980 was the same as the 1982 district; in this case, the respondent would be incorrectly classified as a retained constituent. In the three pre-1982 ANES post-redistricting surveys as well, no direct indicator exists for whether a respondent's district was changed by redistricting. Furthermore, the 1972 ANES only lists the respondent's district number as of that year's election, while no district number information whatsoever is provided in the 1962 and 1952 surveys.

6 The three ANES data sets that are used are the 1990-1992 Merged File, the 2000-2004 Merged File, and the 2012 Time Series Study.

7 Both face-to-face and online respondents included in the 2012 ANES are used in the analysis. 
of the standard errors, an additional problem of single-level analysis that applies specifically to testing of the contextual variables is erroneous assignment of degrees of freedom. Rather than degrees of freedom based on the total number of individual cases, the correct degrees of freedom should be based on the number of groups (Bickel, 2007, 110). Our multilevel estimation is performed using the gllamm (Generalized Linear Latent and Mixed Models) program of STATA.

Because the individual-level dependent variable is whether the respondent voted for the incumbent running in his or her district $(1=$ yes, $0=$ no), binomial logit is used to generate the parameters. Respondents voting in districts without major party competition are excluded, as well as those in districts with major party competition who vote for a minor party candidate. ${ }^{8}$ Individual-level independent variables include the following:

New constituent ( 1 if constituent has been shifted into district as result of redistricting, 0 if retained constituent)

Same partisanship ( 1 if constituent identifies with member's party, 0 otherwise.

Independent leaners are grouped with weak and strong partisans) ${ }^{9}$

Independent partisanship ( 1 if constituent identifies as pure independent, 0 otherwise).

Constituents identifying with the non-incumbent party comprise the reference partisanship category.

District-level contextual variables, which have been merged with the survey data, are:

Campaign spending (ln (incumbent's spending) -ln (challenger's spending). All amounts are in 1990 constant dollars)

Challenger quality ( 1 if challenger has held any kind of elected office, 0 otherwise $)^{10}$

District partisan homogeneity (For Republican incumbent district, homogeneity is mean two- party Democratic presidential vote proportion across all 435 districts minus Democratic presidential vote proportion in district; for Democratic incumbent district, homogeneity is Democratic presidential vote proportion in district minus mean Democratic presidential vote proportion across all districts. In 1992 and 2012, presidential returns are from those same

\footnotetext{
${ }^{8}$ Respondents in the 2002 data set residing in the at-large Vermont district of Independent Bernie Sanders were excluded from the analysis.

${ }^{9}$ Including independent leaners with those who identify from the start as Republicans or Democrats on the ANES's partisanship question is justified, insomuch as leaners demonstrate almost as much party loyalty in House elections as do weak identifiers (Jacobson and Carson, 2016, 151-52).

${ }^{10} \mathrm{I}$ am grateful to Gary Jacobson for providing his data detailing the elected office experience of House challengers.
} 
years; for 2002, returns are from 2000, recomputed to fit the new redrawn district boundaries)

Roll call extremity (For Republican members, extremity is first dimension DW-

Nominate score in current Congress; for Democratic members, extremity is first dimension DW- Nominate score multiplied by -1) ${ }^{11}$

Incumbent's party ( 1 for Republican member, 0 for Democratic member).

The spending variable incorporates natural logarithms to allow increasing campaign expenditures to have diminishing returns. Presidential vote proportions, in accordance with standard practice in congressional election studies, are used to proxy district partisanship because of the strong association between presidential voting and party identification. Republican incumbent districts with Democratic presidential vote proportions below the overall mean, and Democratic incumbent districts with Democratic presidential vote proportions above the overall mean have greater levels of partisan homogeneity. Because more negative DW-Nominate values connote greater roll call liberalism and more positive values connote greater conservatism, multiplying Democratic values by -1 means that higher scores for members of both parties are indicators of greater extremity.

Each of the models to be estimated will include the four cross-level effects that were discussed above, whereby the new constituent variable is interacted with Campaign spending, Challenger quality, District partisan homogeneity, and Roll call extremity. In accordance with our previous arguments, the expectations are that transplanted constituents will, compared with retained constituents, rely more on spending and quality in deciding how to vote, and less on partisan homogeneity and extremity. ${ }^{12}$

Besides the core model delineated above, we also estimate a second model that includes additional interaction terms. Here, two individual-level interactions are introduced: New constituent is interacted with Same partisanship, and with Independent partisanship. The

\footnotetext{
${ }^{11}$ Using the first dimension DW-Nominate score to measure roll call ideology is customary in the congressional literature. It mainly taps between- party conflict over economic policy and accounts for the majority of variance in roll call voting (Poole and Rosenthal, 2007, 32-77).

${ }^{12}$ Were there a general tendency for line drawers to bolster the safety of more marginal incumbents by transferring fellow party partisans to their district, while making safer incumbents less safe by bringing in opposition party voters, the expected negative interaction between the New constituent and District partisan homogeneity variables might then spuriously be made more negative.

Many new voters in the more marginal districts would tend to be pro-incumbent because of their partisanship, whereas many new voters in the safer districts would tend to be anti-incumbent. The likelihood of an inflated negative interaction, however, is checked by including variables for voter partisanship in the equation. Furthermore, the relationship between new voter partisanship and district partisan homogeneity is weak. Combining our two partisanship variables so that incumbent party partisans are coded as 3, independents as 2, and opposition party partisans as 1 , the summary measure correlates with district partisan homogeneity only at .180. (The small positive coefficient, of course, indicates that on the whole safer districts are made slightly safer by redistricting, and less safe districts made slightly more marginal.)
} 
expectation is that transplanted voters, possessing less personal vote information about the incumbent, would vote more heavily on the basis of their partisanship than would retained voters.

\section{The Effects of Contextual Factors on Old and New Constituents}

Table 1 displays the results of the multilevel analysis. Fixed effects parameters are first listed for the independent variables, followed by the variances of the random effects intercepts existing at the two contextual levels. Focusing on the first model, the coefficient of the variable at the center of our inquiry - New constituent - confirms that being a transplanted voter reduces the odds of casting a vote to reelect the incumbent $(\mathrm{p}<.05)$. Interaction of this variable with the campaign-related contextual factors, however, leads to inability to confirm the first two crosslevel hypotheses. The parameter of Campaign spending, which reveals this variable's effect on retained constituents (i.e., when the value of $\mathrm{New}$ constituent equals zero), indicates that greater campaign expenditures for the incumbent relative to those of the challenger make for greater likelihood of a pro-incumbent vote $(\mathrm{p}<.05)$. But contrary to expectations, the interaction term, while having the proper positive sign, is far from being significant, meaning that old and new constituents alike react similarly to this stimulus. Challenger quality, as evidenced by the lack of significance for both the variable by itself as well as its related interaction term, has no effect on either group of constituents.

The third and fourth hypotheses are confirmed in Table 1. District partisan homogeneity significantly influences the vote for old constituents $(\mathrm{p}<.01)$, while the significant negative interaction term for this variable $(\mathrm{p}<.05)$ shows that new constituents are not similarly affected. The negative sum of the two parameters here $-2.615+(-3.179)=-.564-$ indicates that new constituents in response to increasing homogeneity actually experience falloff in their tendency to support the incumbent, but the magnitude of the decline is minimal. (This slight decline itself, not surprisingly, is also insignificant. Were the polarity of Same district reversed so that 1 stands for old constituents and 0 for new constituents, the -.564 parameter then resulting for District partisan homogeneity, which would now directly measure the variable's impact on new constituents, is far from being significant.) Furthermore, retained constituents cast proincumbent votes at a significantly reduced level in response to growing incumbent roll call extremity $(\mathrm{p}<.01)$, but the anti-incumbent effect of extremity for transplanted constituents is significantly less $(\mathrm{p}<.10)$, weak in magnitude $(-1.879+1.048=-.831)$, and, by itself, insignificant. One last feature of the fixed effects parameters - unrelated to our hypotheses, however - is that Republican incumbents tend to be more attractive to voters than are Democratic incumbents $(\mathrm{p}<.10)$. 
Table 1. Multilevel Analysis of the Effects of Contextual Variables on Old and New Constituents, 1992-2012

\begin{tabular}{|c|c|c|}
\hline & Model 1 & Model 2 \\
\hline \multicolumn{3}{|l|}{ Fixed Effects } \\
\hline New Constituent & $\begin{array}{l}-.763^{* *} \\
(.411)\end{array}$ & $\begin{array}{l}-.896^{* *} \\
(.455)\end{array}$ \\
\hline Same partisanship & $\begin{array}{l}4.285^{* * *} \\
(.162)\end{array}$ & $\begin{array}{c}4.194^{* * *} \\
(.183)\end{array}$ \\
\hline Independent partisanship & $\begin{array}{c}2.123^{* * *} \\
(.189)\end{array}$ & $\begin{array}{c}2.165^{* * *} \\
(.225)\end{array}$ \\
\hline Campaign spending & $\begin{array}{l}.118^{* *} \\
(.059)\end{array}$ & $\begin{array}{l}.117^{* *} \\
(.058)\end{array}$ \\
\hline Challenger quality & $\begin{array}{l}-.019 \\
(.235)\end{array}$ & $\begin{array}{l}-.023 \\
(.234)\end{array}$ \\
\hline District partisan homogeneity & $\begin{array}{l}2.615^{* * *} \\
(1.080)\end{array}$ & $\begin{array}{l}2.649^{* * *} \\
(1.072)\end{array}$ \\
\hline Roll call extremity & $\begin{array}{c}-1.879^{* * *} \\
(.605)\end{array}$ & $\begin{array}{c}-1.884^{* * *} \\
(.602)\end{array}$ \\
\hline Incumbent's party & $\begin{array}{l}.430^{*} \\
(.231)\end{array}$ & $\begin{array}{l}.430^{*} \\
(.231)\end{array}$ \\
\hline $\begin{array}{l}\text { New constituent }{ }^{*} \text { Campaign } \\
\text { spending }\end{array}$ & $\begin{array}{c}.043 \\
(.098)\end{array}$ & $\begin{array}{l}.055 \\
(.099)\end{array}$ \\
\hline $\begin{array}{l}\text { New constituent }{ }^{*} \text { Challenger } \\
\text { quality }\end{array}$ & $\begin{array}{l}-.036 \\
(.371)\end{array}$ & $\begin{array}{l}-.038 \\
(.375)\end{array}$ \\
\hline $\begin{array}{l}\text { New constituent }{ }^{*} \text { District } \\
\text { partisan homogeneity }\end{array}$ & $\begin{array}{l}-3.179^{* *} \\
(1.791)\end{array}$ & $\begin{array}{l}-3.356^{* *} \\
(1.814)\end{array}$ \\
\hline $\begin{array}{l}\text { New constituent }{ }^{*} \text { Roll call } \\
\text { extremity }\end{array}$ & $\begin{array}{l}1.048^{*} \\
(.667)\end{array}$ & $\begin{array}{l}1.086^{*} \\
(.675)\end{array}$ \\
\hline $\begin{array}{l}\text { New constituent }{ }^{*} \text { Same } \\
\text { partisanship }\end{array}$ & $\ldots$ & $\begin{array}{l}.295 \\
(.296)\end{array}$ \\
\hline $\begin{array}{l}\text { New constituent }{ }^{*} \text { Independent } \\
\text { partisanship }\end{array}$ & - . & $\begin{array}{l}-.121 \\
(.408)\end{array}$ \\
\hline Constant & $\begin{array}{c}-1.337^{* * *} \\
(.501)\end{array}$ & $\begin{array}{c}-1.305^{* * *} \\
(.500)\end{array}$ \\
\hline \multicolumn{3}{|c|}{ Variances of Random Effects Intercepts } \\
\hline Level 2 (House Districts) & $\begin{array}{l}1.026^{* * *} \\
(.206)\end{array}$ & $\begin{array}{l}1.012^{* * *} \\
(.205)\end{array}$ \\
\hline Level 3 (Years) & $\begin{array}{c}.502 \\
(.446)\end{array}$ & $\begin{array}{l}.498 \\
(.443)\end{array}$ \\
\hline Log likelihood & -1165.011 & -1164.286 \\
\hline
\end{tabular}




\begin{tabular}{|c|c|c|}
\hline$N$ of Respondents & 3099 & 3099 \\
\hline$N$ of House Districts & 557 & 557 \\
\hline$N$ of Years & 3 & 3 \\
\hline \multicolumn{3}{|c|}{$\begin{array}{l}\text { Note: Entries are binomial logit coefficients and standard errors resulting from multilevel analysis. One- tail } \\
\text { tests used to determine significance of all coefficients, except for Incumbent's party and Constant where two- } \\
\text { tail tests apply. }\end{array}$} \\
\hline
\end{tabular}

In the second model, where the two additional, individual-level interactions have been included, a positive sign for the interaction between New constituent and Same partisanship would signify that those identifying with the member's party are more likely to vote their partisanship when they have been moved into a new district by redistricting. While this, in fact, is what emerges, the coefficient is no larger than its standard error. The term for the interaction between new constituent status and independents does not even have the proper positive sign and is much smaller than its standard error. In neither case can it be concluded that party-based voting is more pronounced when other information about the incumbent is circumscribed, as it typically is for new constituents. All other fixed effects terms in model two, of course, are very similar in magnitude to those in the previous model.

The random effects parameters of both models listed in the lower part of the table, which are the estimated variances of the intercepts for the two contextual levels, are significant $(\mathrm{p}<.01)$ at the second, but not the third, level. With all fixed effects accounted for, therefore, the likelihood of voting for the incumbent still varies among congressional districts. However, significant variation at the third level - i.e., among the years of redistricting - does not exist.

All told, these results highlight the importance of accessibility to contextual information that can help guide an electoral decision. In the case of district partisanship and incumbent ideology, as argued above, retained constituents owing to their longer period of district residency can be expected to become more conversant with district partisanship and incumbent ideology than will new constituents. Thus, they should be more able to weigh such information in their voting calculus.

Evidence backing this inference, at least so far as it relates to the incumbent's ideology, can be extracted from the ANES, where in 2002 and 2012 (but not in 1992) respondents were asked to place their member on the seven-point scale of liberalism/conservatism. (No questions in any of the three total surveys relate to respondents' perceptions of constituency partisanship, the variable that was available to Burbank in his previously referenced study.) The difference in voters' inability to offer an ideological placement for their member is as expected, but small in magnitude: 6.1 percent for new constituents, vs. 4.3 percent for old constituents $(p<.05$, one-tail 
t-test $)^{13}$. Greater difference exists, however, with regard to the percentages of those making a placement who select the "neutral" category of $4: 22.1$ percent vs. 16.1 percent $(\mathrm{p}<.01$, one-tail $\mathrm{t}$ test). This hints at the possibility that new constituents are engaging in a greater amount of guesswork, a possibility that we now take up in Table 2.

For this analysis, we create a folded scale of perceived member ideology by recoding original ratings of 1 and 7 ("extremely liberal" and "extremely conservative") into 3, 2 and 6 ("liberal" and "conservative") into 2, 3 and 5 ("slightly liberal" and "slightly conservative") into 1 , and 4 ("moderate/middle of the road") into 0 . Thus, as with the measure of roll call extremity used in Table 1, larger values here once again signify greater extremity in either a liberal or conservative direction. ${ }^{14}$

In Table 2, perceptions of member ideology are related to Roll call extremity and New constituent, plus the cross-level interaction of these two independent variables. Multilevel analysis continues to be performed, employing congressional district and year, respectively, as the second and third contextual levels. Ordered logit now generates the estimates, given that the dependent variable has four categories. For old constituents, perceptions of ideology are very significantly related to actual roll call extremity $(\mathrm{p}<.01)$, reinforcing the finding of past research that constituents have a general sense of where their incumbent stands ideologically. The negative coefficient of the interaction term and its corresponding standard error, however, show that the relationship is significantly weaker for new constituents $(\mathrm{p}<.05)$. In addition, reversing the polarity of Same constituent to directly reveal the effect of extremity on the perceptions of new constituents shows that the resulting 236 coefficient falls far short of significance, meaning that new constituent perceptions of members' ideology simply are not affected by actual ideology. Finally, second level random effects parameters, but not those at the third level, are significant $(\mathrm{p}<.05)$, so ideological perceptions vary from district to district with independent variable impacts accounted for. ${ }^{15}$

\footnotetext{
${ }^{13}$ These percentages are based only on respondents who, on an earlier question asking them to rate their incumbent on the 100-degree feeling thermometer scale, said that they recognized the incumbent's name. The ANES automatically codes respondents citing non-recognition on the thermometer question as unable to place the incumbent's ideology as well. Were these non-recognition respondents included in the calculation along with those specifically saying they could not make an ideological placement, then the nonplacement percentages listed here would be considerably larger, as would be the difference between old and new constituents.

${ }^{14}$ In the 2002 ANES, the labels from most to least extreme were "Strong," "Not Strong," "Leaning," and "Moderate."

${ }^{15}$ The three cut points in Table 2, which are not relevant to the substance of the analysis, are the estimated thresholds differentiating regions on the unobservable continuous variable being proxied by the fourfold dependent variable actually used in the ordinal logit analysis, when all independent variables equal zero. The insignificant coefficient for cut 12 reflects uncertainty in the location of the threshold between the slightly liberal/slightly conservative voters and the liberal/conservative voters.
} 
Table 2. Multilevel Analysis of the Relationship Between Actual Incumbent Roll Call Extremity and Perceptions of Incumbent Extremity Held by Old and New Constituents, 2002-2012

\begin{tabular}{|c|c|}
\hline \multicolumn{2}{|l|}{ Fixed Effects } \\
\hline New constituent & $\begin{array}{c}.232 \\
(.225)\end{array}$ \\
\hline Roll call extremity & $\begin{array}{c}1.096^{* * *} \\
(.228)\end{array}$ \\
\hline New constituent ${ }^{*}$ Roll call extremity & $\begin{array}{c}-.860^{* *} \\
(.388) \\
\end{array}$ \\
\hline \multicolumn{2}{|c|}{ Variances of Random Effects Intercepts } \\
\hline Level 2 (House Districts) & $\begin{array}{l}.092^{* *} \\
(.048)\end{array}$ \\
\hline Level 3 (Years) & $\begin{array}{c}.264 \\
(.271)\end{array}$ \\
\hline Log likelihood & -3312.535 \\
\hline$N$ of Respondents & 2538 \\
\hline$N$ of House Districts & 475 \\
\hline$N$ of Years & 2 \\
\hline \multicolumn{2}{|l|}{ Cut Points } \\
\hline cut11 & $\begin{array}{c}-1.424^{* * *} \\
(.389)\end{array}$ \\
\hline cut 12 & $\begin{array}{c}.036 \\
(.388)\end{array}$ \\
\hline cut13 & $\begin{array}{c}1.905^{* * *} \\
(.390)\end{array}$ \\
\hline \multicolumn{2}{|c|}{$\begin{array}{l}\text { Note: Entries are ordered logit coefficients and standard errors resulting from multilevel } \\
\text { analysis. One-tail tests used to determine significance of all coefficients, except for cut points } \\
\text { where two- tail tests apply. }\end{array}$} \\
\hline
\end{tabular}

In contrast to district partisanship and member ideology, however, campaign-related information arising from candidate spending is equally accessible to both old and new constituents, transmitted over the limited duration of a congressional campaign. Particularly important in this regard is information about the challenger; i.e., research generally has shown that of the two types of spending referenced in the independent variable we have formulated, challenger expenditures are more powerful in attracting votes than are incumbent expenditures (Jacobson and Carson, 2016, 65-70). And it is here where new constituents, who will have been exposed to challenger messages for essentially the same period of time as will retained constituents, should not be at a comparative informational disadvantage. Supporting this contention are the findings of McKee (2008b, 970-75) and of Hayes and McKee (2009, 1011 - 
12), who determine that recognition and recall of challengers - which in good part are driven by campaign advertising - are no lower among transplanted constituents than among retained constituents. ${ }^{16}$ Thus, campaign spending, unlike district partisanship and incumbent ideology, does influence voters regardless of redistricting status, even though the greater influence on new voters that we hypothesized arising from their greater need for electoral cues did not materialize.

Of course, the one contextual variable that failed to have any impact on either old or new constituents is challenger quality. This may well be because of the increased tendency over time for higher quality potential challengers to act strategically in deciding whether to run. As a result of basing their candidacy decisions to a greater extent on whether local and national conditions likely will be more conducive to success for their party, the independent effect of quality has diminished (Jacobson, 2013, 137-38; Jacobson and Carson, 2016, 205). A second possibility for the inconsequential effect of this variable, however, can be ruled out. Even though it was argued above that challenger quality should be considered in its own right rather than simply being proxied in terms of challenger vs. incumbent spending, it is certainly true that the two variables are related, perhaps leading to a collinearity problem. But when the Table 1 estimations are redone leaving out spending, the parameter for quality increases in size, but not nearly enough to approach statistical significance, and the interaction term remains virtually unchanged.

\section{Specifying the Impact of Cross-Level Effects on Members' Reelection Safety}

The final analysis that is performed focuses on the two interactions where contextual variables affected new and old voters differently. Specifically, we address the implications of these differential effects for incumbents' reelection security. With voters' actual values retained on every independent variable used in the first model estimated in Table 1, save the contextual variable being singled out for attention, we simulate their probabilities of casting a proincumbent vote were they all to have the same value, first, on partisan homogeneity, and, then, on extremity. The probabilities, which represent population average impacts, are generated with regard to the prior distribution of the random effects. ${ }^{17}$

The starting and end points of the $\mathrm{x}$ axes in Figures 1 and 2 have been selected to encompass respondents' minimum and maximum values on District partisan homogeneity ($.236, .446)$ and Roll call extremity $(-.076,1.191)$, respectively. We focus in our interpretation on values that span two standard deviations below and two standard deviations above the respective means of .104 and .522 . On partisan homogeneity across this \pm 2 s.d. range, old constituents can be expected to increase their probability of supporting the incumbent from .582 to .698 ; for new constituents, the probability declines negligibly from .606 to .581 . With regard to ideological

\footnotetext{
${ }^{16}$ McKee (2008b, 968-72) and Hayes and McKee (2009, 1010-11) find, in contrast, that recognition and recall of incumbents are considerably higher among retained constituents, understandable in light of their opportunities for exposure to the incumbent across a longer time frame than just the campaign period itself.

${ }^{17}$ More details about this procedure may be found in Skrondal and Rabe- Hesketh (2009, 673-81), who were responsible for developing the gllamm program.
} 
extremity, the comparable movement for old constituents is from .725 to .546 , while the much slighter decline for new constituents is from .634 to .551 .

Particularly interesting in both plots is the fact that the lines for old and new constituents intersect. At very low values of partisan homogeneity and very high values of ideological extremity, new constituents actually have better odds of casting a pro-incumbent vote than do retained constituents, thus nullifying the normally strong anti-incumbent effect of new constituent status. This occurs in districts with a partisan homogeneity value of -.033 or lower (i.e., where the vote proportion for the presidential candidate of the incumbent's party is at least .033 below the overall mean district vote for this presidential candidate), and where the

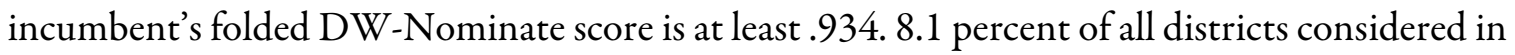
this study are in the former category (incorporating 6.4 percent of all constituents), and 2.9 percent of all districts have members in the latter category (incorporating 3.1 percent of all constituents). In contrast to the preponderance of their colleagues, therefore, the minority of incumbents who represent such districts actually benefit from redistricting that results in relatively large numbers of newcomers being added to their constituencies. And even in districts that are not such outliers, the divergence in pro-incumbent voting between old and new constituents rapidly diminishes as the threshold points are approached, mitigating the damage of large-scale population migration. In either situation, owing to newcomers' relative lack of knowledge about district and member characteristics, they, unlike established constituents, will not be swayed in an anti-incumbent direction by the balance of district partisanship tilting against the member's party, or by the member's ideological extremity. 

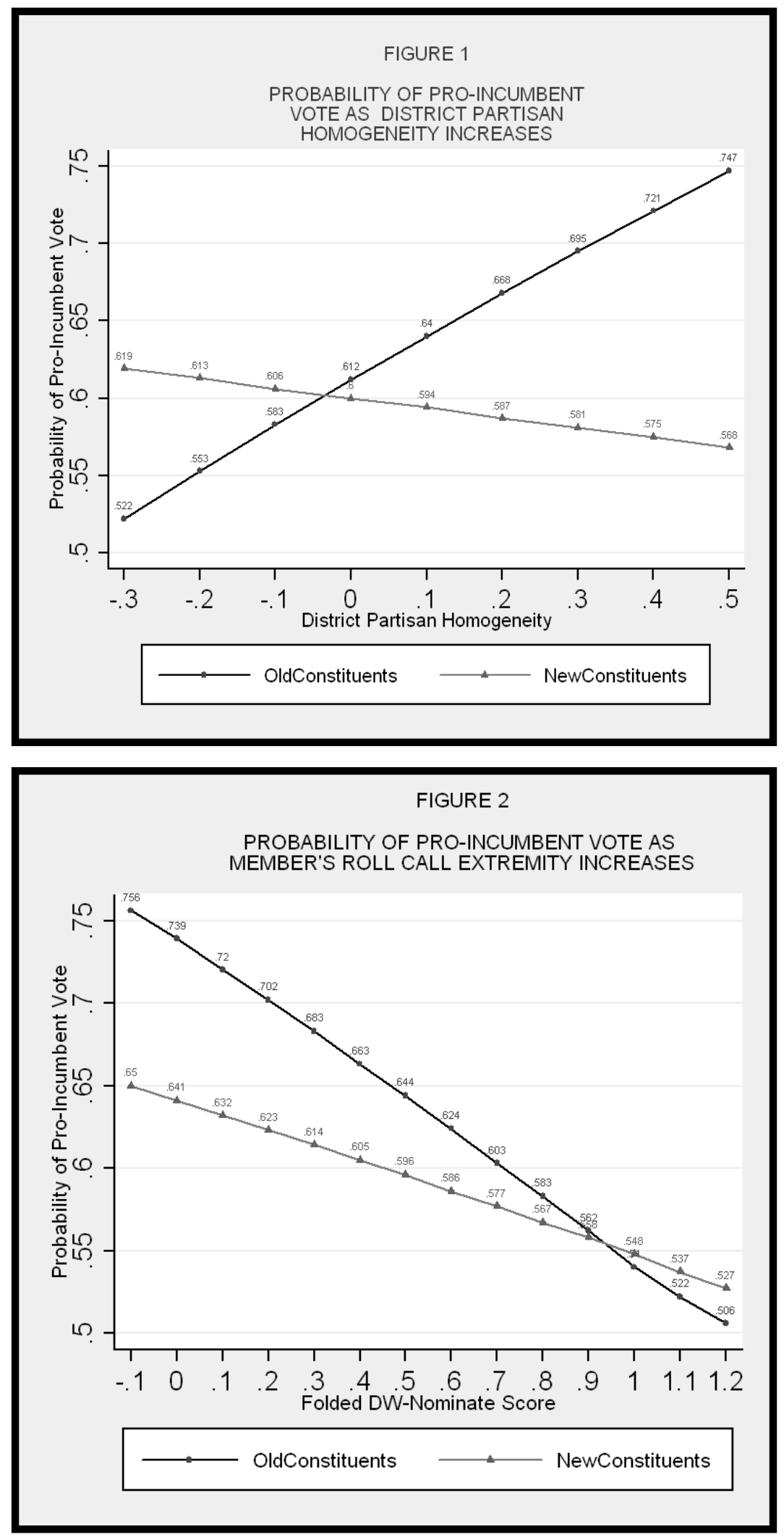


\section{Summary and Conclusions}

This study presents clear evidence that congressional district-level contextual variables matter in helping to explain how transplanted and retained constituents are affected by redistricting. The particular effects of these contextual variables depend upon whether they emerge over the short-term period of the reelection campaign or are of longer duration. Old and new constituents are on an equal footing with regard to exposure to messages about the challenger that are delivered through campaign spending. Thus, both kinds of constituents react similarly to such spending, decreasing in their odds of voting for the incumbent as challenger spending relative to incumbent spending increases. Information about a district's partisan homogeneity and its member's degree of ideological extremity, however, is more likely to be possessed by constituents with longer-standing ties to the district, thus accounting for the finding that only old constituents rely on such information in deciding how to vote.

From the standpoint of reelection safety, the members with the most to gain from new constituents' non-responsiveness to partisan homogeneity and extremity, therefore, are those representing districts with the most unfavorable ratios of same party to opposition party constituents, and those with the most extreme ideology. This is more important for incumbents of the former kind. Aside from the fact that districts with these members are more numerous than are districts with ideological extremists (i.e., as reported above, 8.1 percent v. 2.9 percent), members from districts with unfavorable partisan balances will be much more electorally endangered. Their mean reelection margin across the three election years considered was only 56.6 percent, compared to the mean 67.6 percent margin attained by ideological extremists.

A sense of the contribution that new constituents in the partisan- unfriendly districts make to incumbent reelection success through non- responsiveness to district partisanship can be garnered by calculating, through replication of the procedure used to generate the plot appearing in Figure 1, the expected probability that newcomers in districts below the -.033 partisan homogeneity value where the lines intersect would have supported the incumbent, had they instead been continuing constituents with actual values maintained on all other independent variables. On average, their odds of a pro- incumbent vote would then be reduced by 1.9 percent. And if constituents only from the very most partisan-unfriendly districts (i.e., those with partisan homogeneity values below -.10) are singled out, the expected pro-incumbent odds shrink by 4.7 percent. So, given the fragile reelection margins of incumbents from districts with adverse partisan balances, it seems reasonable that the new constituents are responsible for some of their survival in office.

In sum, the redistricting literature seems short-sighted in its focus on the damage that new constituents can cause incumbents. Newcomers may actually serve the interests of at least a limited number of members, above and beyond the obvious situation whereby the distribution of new constituents' party identification simply is slanted in the direction of an 
incumbent who shares this partisanship. Sometimes ignorance can indeed be bliss, in the sense of newcomer obliviousness to information that, when possessed by constituents with longer- term district attachments, makes them less likely to cast a pro-incumbent ballot.

But even were members aware of such an electoral benefit, they would have to weigh it against the burden - - common to all members undergoing sizable district boundary changes (DeGrazia, 1963, 146; Cain, 1984, 116-17) - - of establishing working relationships with new political and non-political organizations and with local governments in the appended areas. This, combined with the dissipation of the benefit across subsequent post-redistricting elections as new constituents acquire the missing information, might mean on balance that the addition of the new constituents was not a price worth paying. 


\section{References}

Ansolabehere, Stephen, James M. Snyder, Jr., and Charles Stewart, III. 2000. “Old Voters, New Voters, and the Personal Vote: Using Redistricting to Measure the Incumbency Advantage." American Journal of Political Science 44 (January): 17-34.

Ansolabehere, Stephen, James M. Snyder, Jr., and Charles Stewart, III. 2001. "Candidate Positioning in U.S. House Elections." American Journal of Political Science 45 (January): 136-59.

Bickel, Robert. 2007. Multilevel Analysis for Applied Research: It's Just Regression! New York: Guilford Press.

Books, John W., and Charles L. Prysby. 1988. "Studying Contextual Effects on Political Behavior: A Research Inventory and Agenda." American Politics Quarterly 16 (April): 211-38.

Books, John W., and Charles L. Prysby. 1991. Political Behavior and the Local Context. New York: Praeger.

Burbank, Matthew J. 1997. "Explaining Contextual Effects on Vote Choice." Political Behavior 19 (June): 113-32.

Cain, Bruce E. 1984. The Reapportionment Puzzle. Berkeley: University of California Press.

Canes-Wrone, Brandice, David W. Brady, and John F. Cogan. 2002. "Out of Step, Out of Office: Electoral Accountability and House Members' Voting." American Political Science Review 96 (March): 127-40.

Crespin, Michael H. 2005. "Using Geographic Information Systems to Measure District Change, 2000-2002.” Political Analysis 13 (Summer): 253-60.

DeGrazia, Alfred. 1963. Apportionment and Representative Government. New York: Praeger.

Desposato, Scott W., and John R. Petrocik. 2003. “The Variable Incumbency Advantage: New Voters, Redistricting, and the Personal Vote.” American Journal of Political Science 47 (January): 18-32. 
Desposato, Scott W., and John R. Petrocik. 2005. "Redistricting and Incumbency: The New Voter Effect." In Redistricting in the New Millennium, ed. Peter F. Galderisi. Lanham, MD.: Lexington Books.

Erikson, Robert S., and Gerald C. Wright. 2013. "Voters, Candidates, and Issues in Congressional Elections." In Congress Reconsidered, $10^{\text {th }}$ ed., eds. Lawrence C. Dodd and Bruce I. Oppenheimer. Los Angeles: SAGE/CQ Press.

Gelman, Andrew, and Jennifer Hill. 2007. Data Analysis Using Regression and Multilevel/Hierarchical Models. Cambridge: Cambridge University Press.

Gelman, Andrew, David Park, Boris Shor, Joseph Bafumi, and Jeronimo Cortina. 2008. Red State, Blue State, Rich State, Poor State: Why Americans Vote the Way They Do. Princeton: Princeton University Press.

Hayes, Danny, and Seth C. McKee. 2009. "The Participatory Effects of Redistricting.” American Journal of Political Science 53 (October): 1006-23.

Hood, III, M. V., and Seth C. McKee. 2010. “Stranger Danger: Redistricting, Incumbent Recognition, and Vote Choice.” Social Science Quarterly 91 (June): 344-58.

Hood, III, M. V., and Seth C. McKee. 2013. "Unwelcome Constituents: Redistricting and Countervailing Partisan Tides." State Politics and Policy Quarterly 13 (June): 203-24.

Jacobson, Gary C. 2013. "Partisanship, Money, and Competition: Elections and the Transformation of Congress since the 1970s." In Congress Reconsidered, $10^{\text {th }}$ ed., eds. Lawrence C. Dodd and Bruce I. Oppenheimer. Los Angeles: SAGE/CQ Press.

Jacobson, Gary C., and Jamie L. Carson. 2016. The Politics of Congressional Elections, 9th ed. Lanham, MD: Rowman and Littlefield.

McDaniel, Jason A. 2014. "The Politics that Places Make: Contextual Effects and the Future of Political Behavior Research." International Journal of Humanities and Social Science 4 (March): 1-7.

McKee, Seth C. 2008a. "The Effects of Redistricting on Voting Behavior in Incumbent U.S. House Elections, 1992-1994." Political Research Quarterly 61 (March): 122-33. 
McKee, Seth C. 2008b. "Redistricting and Familiarity with U.S. House Candidates." American Politics Research 36 (November): 962-79.

McKee, Seth C. 2013. "Political Conditions and the Electoral Effects of Redistricting." American Politics Research 41 (July): 623-46.

McKee, Seth C., Jeremy M. Teigen, and Mathieu Turgeon. 2006. “The Partisan Impact of Congressional Redistricting: The Case of Texas, 2001-2003.” Social Science Quarterly 87 (June): 308-17.

Pattie, Charles, and Ron Johnston. 2000. “'People Who Talk Together Vote Together': An Exploration of Contextual Effects in Great Britain." Annals of the Association of American Geographers 90 (Issue 1): 41-66.

Petrocik, John R., and Scott W. Desposato. 1998. "The Partisan Consequences of MajorityMinority Redistricting in the South, 1992 and 1994." Journal of Politics 60 (August): 613-33.

Poole, Keith T., and Howard Rosenthal. 2007. Ideology and Congress: A Political-Economic History of Roll Call Voting, $2^{\text {nd }}$ ed. New Brunswick, NJ: Transaction Publishers.

Rush, Mark E. 2000. Does Redistricting Make a Difference?: Partisan Representation and Electoral Behavior. Lanham, MD: Lexington Books.

Skrondal, Anders, and Sophie Rabe-Hesketh. 2009. "Prediction in Multilevel Generalized Linear Models." Journal of the Royal Statistical Society: Series A 172 (June): 659-87.

Steenbergen, Marco R., and Bradford S. Jones. 2002. "Modeling Multilevel Data Structures.” American Journal of Political Science 46 (January): 218-37.

Winburn, Jonathan, and Michael W. Wagner. 2010. "Carving Voters Out: Redistricting's Influence on Political Information, Turnout, and Voting Behavior.” Political Research Quarterly 63 (June): 373-86.

Yoshinaka, Antoine, and Chad Murphy. 2011. "The Paradox of Redistricting: How Partisan Mapmakers Foster Competition but Disrupt Representation.” Political Research Quarterly 64 (June): 435-47. 